\title{
ULTRA THIN EPIDERMAL SKIN GRAFTING FOR STABLE VITILIGO: A COST EFFECTIVE AND COSMETICALLY SATISFYING TREATMENT OPTION
}

Padmaja Pinjala1 ${ }^{1}$ T. Rajeev Singh² ${ }^{2}$ Ch. Madhu Babu ${ }^{3}$, Deepthi Prasad ${ }^{4}$

\section{HOW TO CITE THIS ARTICLE:}

Padmaja Pinjala, T. Rajeev Singh, Ch. Madhu Babu, Deepthi Prasad. "Ultra Thin Epidermal Skin Grafting for Stable Vitiligo: A Cost Effective and Cosmetically Satisfying Treatment Option". Journal of Evolution of Medical and Dental Sciences 2015; Vol. 4, Issue 43, May 28; Page: 7436-7441, DOI: 10.14260/jemds/2015/1079

ABSTRACT: Ultrathin epidermal skin grafting is the simplest aesthetic procedure for stable vitiligo. Various surgical procedures such as miniature Punch Grafting, Suction blister grafting, Mash technique etc are available for covering stable vitiligenous depigmented area. This article reviews about the relatively easy and new technique in treating stable Vitiligo. Ultra thin epidermal skin grafting involves transfer of a very thin layer of skin including epidermis to achieve transfer of melanocytes from donor graft to the underlying dermabraded vitiligenous recipient area.

KEYWORDS: STSG, USTG, Stable Vitiligo, Melanocytes.

INTRODUCTION: Ultrathin epidermal skin grafting is the most common procedure being done in stable vitiligo cases. Vitiligo is a common depigmented disorder characterized by white patches. It is a common disorder with high Psycho-social stigma.(1) Surgical methods become important in cases where medical therapy fails to cause repigmentation in residual cases.(1) Haxthausen first transplanted thin split thickness skin graft from normal to vitiligenous skin in 3 cases to study the pathogenesis of the disease.(2) Bhel in 1964, was first to report the use of thin thresh skin graft to treat vitiligenous patch.(3) Khan et al.,(4) used a modification of this technique, where they used ultrathin split thickness grafts $(<0.08-0.15 \mathrm{~mm})$. Olsan \& Juhlin,(5) employed this technique to transplant melanocytes to the vitiligenous area.

TECHNIQUE: The ideal surgical treatment for vitiligo should provide complete or near complete repigmentation in the shortest possible time with minimal discomfort to the patient and no or minimal side effects and should be cheap. Currently available methods are classified as Grafting and Non-Grafting techniques. Table 1 . shows the various techniques available for treating recalcitrant vitiligo patches.(6)

\begin{tabular}{|c|c|c|}
\hline \multicolumn{2}{|c|}{ GRAFTING TECHNIQUES } & NON GRAFTING TECHNIQUES \\
\hline TISSUE GRAFTS & CELLULAR GRAFTS & \\
\hline 1. Mini Punch & $\begin{array}{l}\text { 1. Non cultured cell } \\
\text { suspension- Epidermal } \\
\text { \& Follicular Cells }\end{array}$ & 1. Micro pigmentation \\
\hline $\begin{array}{l}\text { 2. Suction Blister } \\
\text { grafting }\end{array}$ & $\begin{array}{l}\text { 2. Cultured Melanocytes/ } \\
\text { Keratinocytes Grafts }\end{array}$ & 2. Excision/Closure \\
\hline $\begin{array}{l}\text { 3. Thin split thickness } \\
\text { grafting }\end{array}$ & & 3. Dermabrasion, Chemabrasion \\
\hline $\begin{array}{l}\text { 4. Hair follicle grafts, } \\
\text { Smash Grafts, Mesh } \\
\text { Grafts }\end{array}$ & & $\begin{array}{l}\text { 4. Lasers and light therapy systems - } \\
\text { Excimer laser/light, targeted } \\
\text { phototherapy. }\end{array}$ \\
\hline
\end{tabular}

Table 1: Various Surgical Procedures 


\section{ORIGINAL ARTICLE}

Ultra thin epidermal skin grafting involves transfer of very thin layer of skin including epidermis to achieve transfer of melanocytes from donor grafts to underlying dermabraded vitiligenous areas.

MATERIAL \& METHODS: Study design is a prospective study. Sample study includes 11 cases of stable vitiligo and 1 case of Halo nevus. After thorough history taking, clinical examination and investigations, cases were posted for surgery after taking the informed and written consent.

SELECTION OF PATIENT: Patients having segmental, focal or residual vitiligo were included in the study. These patients were stable for at least 6 months and not showing response to any medical treatment. Patients with history of keloid formation, H/O Herpes, Koebner's phenomenon, patients not willing for surgery and pregnant females were excluded from the study.

SURGICAL TECHNIQUE: Antero-lateral aspect of thighs and medial aspect of the arm were selected as donor areas for below waist and above waist lesions respectively for proper colour match. Shaving or plucking of the hair of donor area is done. Topical anesthesia is given with EMLA under occlusion for minimum of $1 \frac{1}{2}$ hours. Appropriate traction pressure is applied on both the sides to flatten the donor area. A willikinson sword shaving blade mounted on a straight artery forceps is used to harvest the graft. The cutting edge is held parallel to skin surface and free sliding to and fro motion is then employed to cut tangentially throughout the upper dermis until there is pin point bleeding. The angle at which the blade is applied controls the depth of the graft. The graft is transferred to a Petri dish containing normal saline. Haemostasis is attained by applying pressure and the donor area is dressed with sofra tulle.

A good ultrathin graft is one, which is translucent, floats in normal saline and doesn't role, looks similar on both epidermal and dermal sides (Glistening on dermal side, dull on epidermal side).

After surgical cleaning, the recipient area is anesthetized with $1 \%$ lidocaine. Dermabrasion is done with electrical dermabrador with a diamond fraise and piece. The graft is transferred on to the dermabraded recipient area taking care to place the dermal surface facing down. Immobilization is achieved with fevi quick at the margins of the graft and pressure bandage is applied. Strict immobilizations of grafted site is attained. Antibiotics and anti inflammatory drugs are prescribed. $1^{\text {st }}$ dressing is done at the end of $1^{\text {st }}$ week. No complications were developed during or after the procedure. Figure1. showing the equipments required for the surgery.

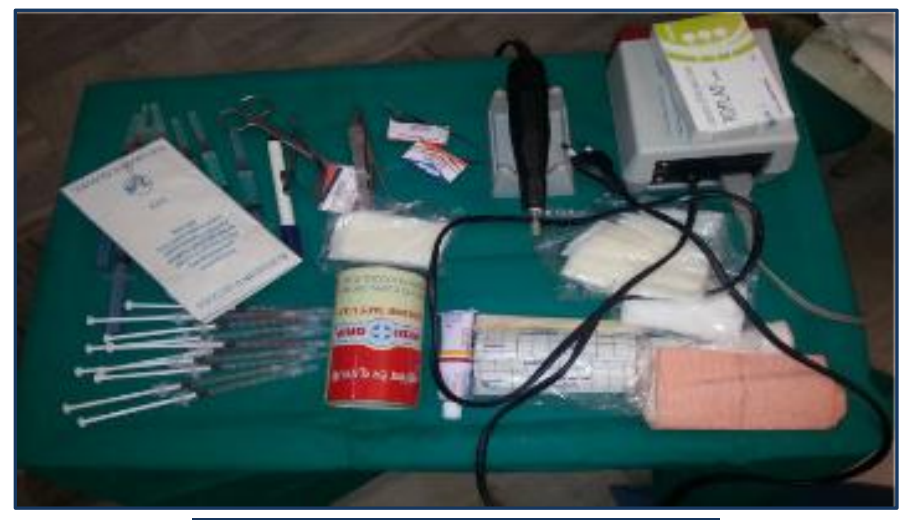

Fig. 1: Equipment required 
OBSERVATIONS: The results are graded as Excellent, Good and Average depends upon the response. Few cases which not shown much improvement were kept on oral PUVA which showed good response. Out of 12 cases, 4 cases showed excellent response, 5 cases showed good response and 3 cases showed average response. The said cases were found not responding to routine medical treatment were opted for this specific surgical techniques. Table 2. shows the sites involved, and Table 3. shows the Master chart.

\begin{tabular}{|c|c|c|c|}
\hline $\begin{array}{l}\text { Sl. } \\
\text { No }\end{array}$ & Site & $\begin{array}{l}\text { Oral } \\
\text { puva }\end{array}$ & Response \\
\hline 1 & Both Lips & + & Excellent \\
\hline 2 & Rt. Upper eyelid & - & Excellent \\
\hline 3 & Lower Lip & + & Excellent \\
\hline 4 & Lateral aspect of Left calf & - & Excellent \\
\hline 5 & Glans Penis & - & Good \\
\hline 6 & Forehead & + & Good \\
\hline 7 & Both Shins & + & Good \\
\hline 8 & Dorsal aspect of Leg foot & + & Good \\
\hline 9 & $\begin{array}{c}\text { Both upper eye lids, } \\
\text { above upper lip }\end{array}$ & + & Average \\
\hline 10 & Halo nevus & - & Lost follow up \\
\hline 11 & Both lips & + & Excellent \\
\hline 12 & Cheeck & - & Excellent \\
\hline
\end{tabular}

\begin{tabular}{|c|c|c|c|c|c|}
\hline $\begin{array}{c}\text { Sl. } \\
\text { No. }\end{array}$ & $\begin{array}{c}\text { Patient } \\
\text { ID }\end{array}$ & $\begin{array}{c}\text { Age/ } \\
\text { Sex }\end{array}$ & Site & $\begin{array}{c}\text { Oral } \\
\text { Puva }\end{array}$ & Response \\
\hline 1 & 1 & $25 / \mathrm{F}$ & Both lips & + & Excellent \\
\hline 2 & 2 & $27 / \mathrm{F}$ & Right Upper eyelid & - & Excellent \\
\hline 3 & 3 & $28 / \mathrm{F}$ & Lower lip & + & Excellent \\
\hline 4 & 4 & $19 / \mathrm{F}$ & Lateral aspect of left calf & - & Excellent \\
\hline 5 & 5 & $30 / \mathrm{M}$ & Glans Penis & - & Good \\
\hline 6 & 6 & $26 / \mathrm{F}$ & Forehead & + & Good \\
\hline 7 & 7 & $17 / \mathrm{F}$ & Both Shins & + & Good \\
\hline 8 & 8 & $20 / \mathrm{F}$ & Dorsal aspect of leg foot & + & Good \\
\hline 9 & 9 & $40 / \mathrm{F}$ & Halo nevus & - & Good \\
\hline 10 & 10 & $25 / \mathrm{M}$ & $\begin{array}{c}\text { Both upper eye lids, } \\
\text { above upper lip }\end{array}$ & + & Average \\
\hline 11 & 11 & $26 / \mathrm{M}$ & Both lips & + & Excellent \\
\hline 12 & 12 & $35 / \mathrm{M}$ & Cheeck & - & Excellent \\
\hline
\end{tabular}

Table 3: Master Chart 


\section{ORIGINAL ARTICLE}

Few photographs showing pre and post operative results.

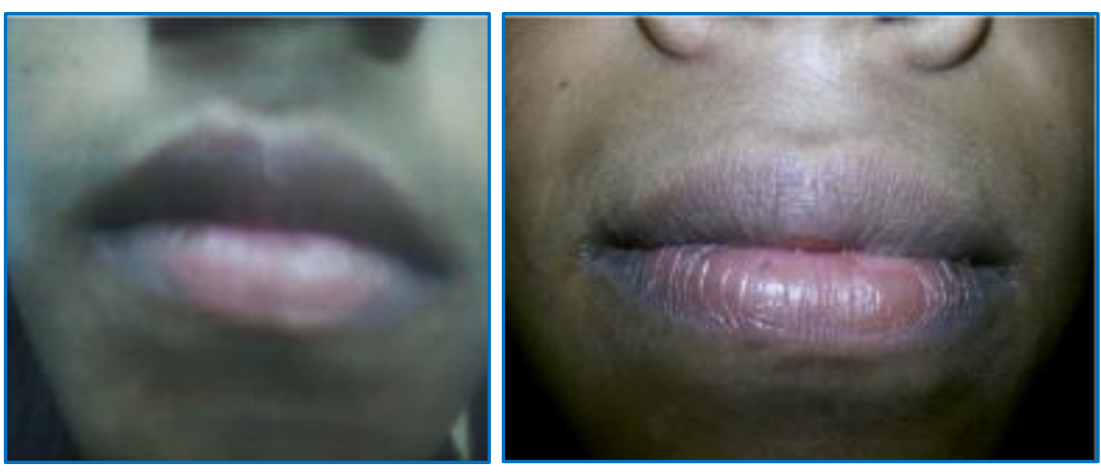

Fig. 2: Pre and Post op photos of lower lip
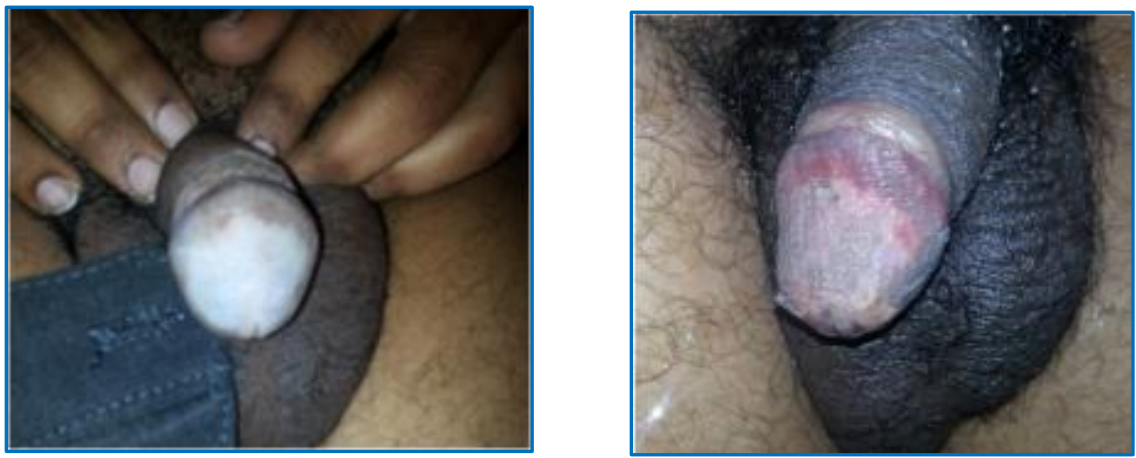

Fig. 3: Vitiligo Patch on Penis
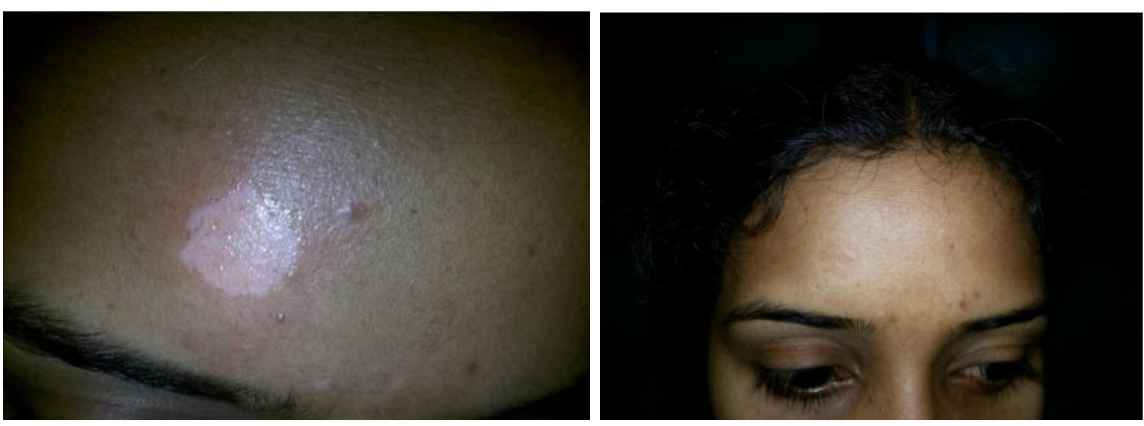

Fig. 4: Vitiligo patch on Fore Head

DISCUSSION: The systematic reviews by Njoo et al,(7) on autologous transplantation methods show that the highest mean success rates were achieved by STSG, which range from $87 \%$ to $91 \%$. Agrawal et al,(8) treated 32 sites in 21 patients with stable refractory vitiligo using this type of technique. They reported $100 \%$ repigmentation in the remaining patches. Compared to other techniques ultra thin epidermal skin grafting appears to be better than conrol, suction blister or combined split thickness.

Compared to the suction blister grafting ultra thin epidermal skin grafting can cover a larger surface area. Ozdemir et al,(9) demonstrated a higher percent of repigmentation with this ulta thin 
epidermal skin graft technique than the suction blister grafting in a single patient. Khandpur et al,(10) as compared to mini punch grafting this technique produces far more cosmetically superior results and matching over larger areas. In our opinion, the ultrathin skin graft technique is found to be simple, economical, less time consuming with good cosmetic appearence. Small grafts can be used to cover larger areas.

This is a safe procedure in cases of stable vitiligo. However, it requires a fare amount of skill. Post operative complications were minimal. There was no graft rejection in any of the patients. Imran mazid et al,(11) observed repigmentation is greater in patients treated with photo chemotherapy plus ultra thin epidermal skin graft versus punch grafts alone.

\section{REFERENCES:}

1. Indian J Dermatol. A 2009 Apr-Jun; A54 (2) : 150- 158. DOI: AA 0. 4103/0019-5154. 53196.

2. Falabella R. History and chronology of development of surgical therapies for vitiligo. In: Gupta $S$, Olsson MS, Kanwar AJ, Ortonne JP (Eds). Surgical Management of Vitiligo, $1^{\text {st }}$ Edition. Massachusetts USA: Blackwell Publishing; 2007: 41-8.

3. Behl PN. Treatment of Vitiligo with homologous thin Thiershas Skin Grafts. Curr Med Pract. 1964: 8: 218-21.

4. Kahn AM, Cohen MJ - Vitiligo: Treatment by Dermabrasion and Epidermal sheet grafting. J American Academy Dermatology 1995: 33: 646-8.

5. Olsson MJ, Juhlin L - Epidermal sheet grafts for repigmentation of vitiligo and piebaldism. with a review of surgical techniques.

6. ASCI text book on cutaneous and Aesthetic surgery, 24A overview of vitiligo surgery pg no. 327

7. Njoo MD, Wasterhef W, Bos J D, et al. A systematic review of autologous transplantation methods in vitiligo. Arch Dermatol, 1998; 134: 1543-9.

8. Agrawal K, Agrawal A vitiligo; repigmentation with Dermabrasion and thin split thickness skin graft. Dermatol surg. 1995; 21: 295-300.

9. Ozdemir $\mathrm{M}$, Cetinkale $\mathrm{O}$, Wolf $\mathrm{R}$ et al, comparison of two surgical approaches for treating vitiligo: a preliminary study. Int J Dermatol. 2002; 41: 135-8.

10. khandpur S, Sharma V K, Manchanda Y. comparison of mini punch grafting versus split-skin grafting in chronic stable vitiligo. Dermatol surg. 2005; 31: 436-41.

11. Mazid I,Imran S. Ultra thin split thickness skin grafting fallowed by narrow band UVB therapy for stable vitiligo: An effective and cosmetically satisfying treatment option. Ind J Dermatol Venereol Leprol. 2012 Mar- Apr; 78(2): 159-64. 


\section{ORIGINAL ARTICLE}

\section{AUTHORS:}

1. Padmaja Pinjala

2. T. Rajeev Singh

3. Ch. Madhu Babu

4. Deepthi Prasad

\section{PARTICULARS OF CONTRIBUTORS:}

1. Associate Professor, Department of DVL, Osmania Medical Collage.

2. Assistant Professor, Department of DVL, Osmania Medical Collage.

3. Professor, Department of DVL, Osmania Medical Collage.

FINANCIAL OR OTHER COMPETING INTERESTS: None
4. Senior Resident, Department of DVL, Osmania Medical Collage.

\section{NAME ADDRESS EMAIL ID OF THE} CORRESPONDING AUTHOR:

Dr. Padmaja Pinjala,

\# 3-5-803/1,

King Koti-Sher Gate,

Opp. B. V. Bhavan,

Hyderabad-500029.

E-mail: drpadmajapinjala@gmail.com

Date of Submission: 07/05/2015.

Date of Peer Review: 08/05/2015.

Date of Acceptance: 22/05/2015.

Date of Publishing: 26/05/2015. 